\title{
Evaluation of Comparative Management of Expanded Program Immunization for Children in Iran and in the World
}

\author{
Fereshteh Farzianpour ${ }^{*}$, Kobra Bamdad Mehrabani' ${ }^{2}$, Nayeb Fadaei Dehcheshmeh ${ }^{1}$, \\ Mohammad Azmal ${ }^{1}$ \\ ${ }^{1}$ Department of Health Management and Economics, School of Public Health, Tehran University of Medical \\ Sciences, Tehran, Iran \\ ${ }^{2}$ Department of Immunology, School of Medicine, Tehran University of Medical Sciences, Tehran, Iran \\ Email: ${ }^{\text {farzianp@sina.tums.ac.ir }}$
}

Received 13 September 2014; revised 28 October 2014; accepted 13 November 2014

Copyright (C) 2014 by authors and Scientific Research Publishing Inc.

This work is licensed under the Creative Commons Attribution International License (CC BY). http://creativecommons.org/licenses/by/4.0/

(c) (i) Open Access

\begin{abstract}
Background: EPI is one of the most cost-effective public health interventions that have already been identified. Mass vaccination is one of the most effective public health strategies that lead to a dramatic reduction in the incidence of many infectious diseases. This is a descriptive study (ecological exploratory) where data about the status of routine immunization of children under 6 years in 6 selected countries in terms of the routine immunization programs in each country, the coverage and reported cases of vaccine-preventable diseases from 2006 to 2008 were collected assuming that each country is a representative of a Continent; data about the status of Iran were also collected and a comparative study was performed in the next step. It is worth mentioning that selecting these countries was according to health experts to consolidate the data. Collection tools are data of international (WHO and UNICEF) and national organizations of the above countries. In all countries surveyed, triple vaccine, vaccines of polio, hepatitis $B$, measles, rubella and mumps are part of the routine immunization program for children under the age of 6 years, with the explanation that in South Africa only measles vaccine is injected instead of measles, rubella and mumps vaccines. The coverage rate of the vaccine and other vaccines in Iran was the best compared to other countries. This represents the widespread activity of health care systems of the country in the field of vaccination and tireless efforts of healthcare workers and health centers.
\end{abstract}

\section{Keywords}

Evaluation, Comparative Management, Program Immunization, Children, Iran, World

\footnotetext{
${ }^{*}$ Corresponding author.
}

How to cite this paper: Farzianpour, F., Mehrabani, K.B., Dehcheshmeh, N.F. and Azmal, M. (2014) Evaluation of Comparative Management of Expanded Program Immunization for Children in Iran and in the World. Health, 6, 2697-2704. 


\section{Introduction}

Infectious diseases are responsible for a third of all deaths around the world and cause the death of at least 15 million people annually in the world. Of these, more than 5 million are children under the age of 5 years. The most effective way to reduce morbidity and mortality from infections is the immunization of predisposed individuals. Except for the use of safe and healthy water, no further action (even the use of antibiotics) is effective in reducing mortality and population growth [1].

After the successful eradication of smallpox as one of the greatest achievements in the field of public health, World Health Organization, sought for other activities on the basis of the obtained results, until the expanded immunization program (EPI) was developed in 1974, between 1974 and 1980; other organizations such as UNICEF ran programs for immunization. Vaccines used in the EPI program from 1974 onwards included vaccines for tuberculosis, polio, measles, whooping cough, tetanus and diphtheria toxoids and vaccines of hepatitis, measles, rubella, mumps, measles and yellow fever instead (in countries with local outbreaks of the disease) were added later [1]-[3].

EPI is one of the most cost-effective public health interventions that have already been identified [3]. Mass vaccination is one of the most effective public health strategies that lead to a dramatic reduction in the incidence of many infectious diseases [4].

Vaccination is one of the most important public health interventions in the past century that saves lives of millions of people from infectious diseases. 130 annually million children are born and about 30 million of them have no access to vaccines [5]. Childhood vaccinations have major effect on reducing and eliminating most causes of morbidity and mortality among children. Annual monitoring of vaccination coverage levels over time is necessary to determine the low coverage of vaccination [6]. Also the awareness of the vaccination coverage is necessary to formulate strategies to achieve the objectives of the vaccination program, and evaluate the strategies [4]. On the other hand, the vaccination coverage will be considered as the most common performance indicator of immunization program [7]. In fact, immunization coverage is a health output with the final outcome of reducing the incidence of disease [8].

Despite the low cost of routine childhood immunization, nearly 3 million children continue to die from vaccine-preventable diseases each year. Therefore, achieving and maintaining high levels of immunization coverage should be a priority for all health systems. To monitor the progress of achieving this goal, immunization coverage data should be considered as an indicator of the health system's capacity to provide services to the most vulnerable members of society. Measuring immunization coverage is relatively simple and inexpensive and can lead to valid and reliable results [8].

Despite the successes achieved, currently about a quarter of children in the world (34 million infants) have not been vaccinated against deadly diseases. The future universal goal of immunization is to create vaccination coverage of $90 \%$ at a national level and $80 \%$ at a regional level for all children under the age of one year until 2010 (1 and 2).

This study aimed to compare the expanded immunization programs in Iran and other countries of the world (United States of America, Canada, Australia, Britain, China and South Africa) respecting routine immunization program, the amount of coverage and reported cases of vaccine-preventable diseases since 2006 to 2008.

\section{Materials and Methods}

This is a descriptive study (ecological exploratory) where data about the status of routine immunization of children under 6 years in 6 selected countries in terms of the routine immunization programs in each country, the coverage and reported cases of vaccine-preventable diseases from 2006 to 2008 was collected assuming that each country is a representative of a Continent, data about the status of Iran was also collected and a comparative study was performed in the next step. It is worth mentioning that selecting these countries was according to health experts to consolidate the data. Collection tools are data of international (WHO and UNICEF) and national organizations of the above countries.

International organizations also obtain data as follows [9]:

1. Reported administrative data by Member States of WHO

2. Previous data maintained by UNICEF

3. Published texts, coverage basic results and techniques

4. Available surveys not published by the state Department of Health 
In addition to the above, in some cases, UNICEF design and implement surveys in countries, finally, The WHO and UNICEF work on matching data collected from the countries at the international level [9].

The immunization program means the types of vaccines used in immunization programs and their implementation time in the countries.

The coverage means the estimated number of children covered by the country's routine immunization program to the total population of children [9] [10].

Coverage is usually calculated separately for each antigen and vaccine shot (vaccine No.) [9]. Given that each vaccine shot is following a previous program and, for example the third shot means that the first and second shots have already been received, in this article the coverage of the last vaccination was considered. Selecting the target population is different based on the policy of each country.

The incidence of preventable diseases means the number of reported cases of diseases covered by vaccination (VPDs) on the basis of data for each country reported to the World Health Organization [9].

\section{Results}

In all countries surveyed, triple vaccine, vaccines of polio, hepatitis B, measles, rubella and mumps are part of the routine immunization program for children under the age of 6 years, with the explanation that in South Africa only measles vaccine is injected instead of measles, rubella and mumps vaccines. Due to the low prevalence of tuberculosis in developed countries like America, Australia and Canada, the BCG vaccine was evaluated in vaccination programs of other countries.

Varicella vaccine in Australia, America and Canada is part of the routine immunization program. Meningitis, haemophilus and influenza vaccines run in all countries except China and Iran. In China, only Japanese encephalitis and hepatitis A vaccines are inoculated in addition to routine vaccines. Rotavirus vaccine runs in Australia and South Africa (Table 1).

The results of Table 2 show that:

In all surveyed countries, the routine program begins at birth except Canada where Hepatitis B vaccine begins in the first touch (it is the most likely that the first touch is at birth).

In all countries, Hepatitis B vaccine is injected at birth. In Iran, China, South Africa and the UK in addition to hepatitis B, BCG vaccine is given as well, and in Iran and South Africa the oral polio vaccine is also administrated at birth.

The hepatitis B vaccination program begins at the time of birth in all target countries except South Africa (at the age of 1.5 months). Second and third doses of hepatitis B are at 2 and 6 months of age in Iran, England and America, at one and 6 months of age in China, at 2.5 and 3.5 months of age in South Africa, at 2 and 4 months of age in Australia and at 1 and 3 months of age in Canada.

Polio vaccine was given in two different ways, OPV and IPV, in different countries. The countries using OPV include Iran (6 doses), South Africa (5 doses) and China (4 doses) and in Canada (5 doses), America, Australia and the United Kingdom (4 doses) IPV was used.

Table 1. Type of vaccines used in routine immunization program for children under six years.

\begin{tabular}{ccl}
\hline Row & Country & Routine immunization program (vaccine type) \\
\hline $\mathbf{1}$ & Iran & BCG-DTP-OPV-HepB-MMR \\
$\mathbf{2}$ & China & BCG-DTP-OPV-HepB-MR-HepA-JANENC-MenC \\
$\mathbf{3}$ & South Africa & BCG-DTP-OPV-HepB-M-Hib-PNEu-RV \\
$\mathbf{4}$ & Australia & DTP-IPV-HepB-MMR-Hib-RV-MenC-VAR-INFLU \\
$\mathbf{5}$ & England & BCG-DTP-IPV-HepB-MMR-PNEu-MENC \\
$\mathbf{6}$ & Canada & MenC-PNEu-MENC-DTP-IPV-HepB-MMR-Hib \\
$\mathbf{7}$ & America & Hib-PNEu-VAR-DTP-IPV-HepB-MMR \\
\hline
\end{tabular}

MMR: measles, measles, and mumps; HepB: hepatitis B; OPV: oral polio; DTP: diphtheria, tetanus, pertussis; BCG: TB; MenC: meningococcal disease; HepA: hepatitis; AJANENC: Japanese encephalitis; RV: Rotavirus; PNEu: Pneumococcus; Hib: Haemophilus influenza; M: Measles; INFLU: Influenza; VAR: Chickenpox; IPV: injectable polio; MR: measles, mumps. 
DTaP vaccine is injected in Canada, America, China and DTwP vaccine is injected in Iran and South Africa in five steps, in contrast, in Australia and Britain DTaP is offered in 4 steps (It is noteworthy that in both Canada and Australia that triple DTaP vaccine is available in various ways, such as DTaP HeP IPV, DTaP HiB HeP IPV and DTaP IPV And in South Africa DTP vaccine is available as DTwP Hib and DTwP HepB IPV).

In all the countries surveyed, MMR vaccine is injected twice at the ages of 12 months and 6 - 4 years, with the exception of South Africa where measles is injected at the ages of 9 months and 18 months, and in China, at the age of 8 months, measles and rubella (MR) as well as Japanese encephalitis and at the age of 18 months, measles, rubella, mumps (MMR) with Japanese encephalitis are administered.

Pneumococcal vaccine, except for China and Iran, in other countries examined is provided in 3 to 4 doses according to Table 1.

Among the countries studied, the rotavirus vaccine is offered only in South Africa (2 times), Australia and the America (3 times).

Haemophilus influenza is not offered in Iran and China and in other countries is injected in 3 - 4 times (See Table 2).

Chickenpox Vaccine is injected only in America (in two steps at the ages of 12 - 18 months and 4 - 6 years) and Canada (in one step at the age of 12 months) and Australia (once in 18 months).

Meningococcal vaccine is not offered in Iran, China, South Africa and America in the immunization program for children and is injected in 1 - 3 shots in Australia, Britain and Canada (Table 2).

Table 3 shows: Disease cases reported according to the World Health Organization between 2006 and 2008.

Table 4 shows that: Vaccination coverage rates in the surveyed countries have increased between 2006 and 2008 or remained unchanged, with the exception of the third dose of polio coverage in Canada that was $94 \%$ in

Table 2. Routine immunization program schedual.

\begin{tabular}{|c|c|c|c|c|c|c|c|c|c|c|c|c|}
\hline $\begin{array}{l}\text { Time } \\
\text { country }\end{array}$ & $\begin{array}{c}\text { At } \\
\text { birth }\end{array}$ & $\begin{array}{l}\text { One- } \\
\text { month }\end{array}$ & 2-months & 3-months & 4-months & 5-months & 6-months & 8-months & 9-months & $\begin{array}{l}12-15- \\
\text { months }\end{array}$ & $\begin{array}{l}15-18- \\
\text { months }\end{array}$ & $\begin{array}{l}4-6- \\
\text { years }\end{array}$ \\
\hline Iran & $\begin{array}{l}\text { BCG } \\
\text { HepB } \\
\text { OPV }\end{array}$ & - & $\begin{array}{l}\text { OPV } \\
\text { DTwP* } \\
\text { HepB }\end{array}$ & - & $\begin{array}{l}\text { OPV } \\
\text { DTwP }\end{array}$ & & $\begin{array}{l}\text { OPV } \\
\text { DTwP }\end{array}$ & - & - & MMR & $\begin{array}{l}\text { OPV } \\
\text { DTwP }\end{array}$ & $\begin{array}{l}\text { DTwP } \\
\text { OPV } \\
\text { MMR }\end{array}$ \\
\hline China & $\begin{array}{l}\text { BCG } \\
\text { HepB }\end{array}$ & НерВ & OPV & $\begin{array}{l}\text { OPV } \\
\text { DTaP }\end{array}$ & $\begin{array}{l}{ }^{* *} \mathrm{DTaP} \\
\text { OPV }\end{array}$ & DTaP & НерВ & $\begin{array}{c}\text { MR } \\
\text { Encjap }\end{array}$ & - & - & $\begin{array}{l}\text { DTap } \\
\text { HepA } \\
\text { MMR } \\
\text { Encjap }\end{array}$ & $\begin{array}{l}\text { OPV } \\
\text { DT }\end{array}$ \\
\hline $\begin{array}{l}\text { South } \\
\text { Africa }\end{array}$ & OPV & $\begin{array}{c}\text { (OPV } \\
\text { RV } \\
\text { HepB } \\
\text { PNEu } \\
\text { DTwP Hib } \\
\text { IPV) }\end{array}$ & - & $\begin{array}{c}\text { (DTwP } \\
\text { IpV } \\
\text { Hib } \\
\text { Hep) }\end{array}$ & $\begin{array}{c}\text { (RV } \\
\text { DTwP } \\
\text { IPV } \\
\text { Hib } \\
\text { Hep B } \\
\text { PNEu) }\end{array}$ & - & - & - & PNEuM & - & $\begin{array}{c}\text { DTwP } \\
\text { IPV } \\
\text { Hib } \\
\text { M }\end{array}$ & Td \\
\hline Australia & НерВ & - & $\begin{array}{c}\text { PNEu } \\
\text { RV } \\
\text { DTap IPV } \\
\text { HiB } \\
\text { HepB }\end{array}$ & - & $\begin{array}{c}\text { PENu } \\
\text { RV } \\
\text { DTap } \\
\text { IPV } \\
\text { Hib } \\
\text { HepB }\end{array}$ & - & $\begin{array}{l}\text { DTaP } \\
\text { HepB }\end{array}$ & - & - & $\begin{array}{l}\text { MMR } \\
\text { Hib } \\
\text { MenC }\end{array}$ & VAR & $\begin{array}{l}\text { MMR } \\
\text { DTaP } \\
\text { IPV }\end{array}$ \\
\hline England & $\begin{array}{l}\text { (BCG } \\
\text { HepB) }\end{array}$ & - & $\begin{array}{l}\text { DTtaP } \\
\text { Hib } \\
\text { IPV } \\
\text { HepB } \\
\text { PENu }\end{array}$ & $\begin{array}{c}\text { DTtap } \\
\text { Hib } \\
\text { IPV } \\
\text { MenC }\end{array}$ & $\begin{array}{l}\text { DTap } \\
\text { Hib } \\
\text { IPV } \\
\text { PENu } \\
\text { MenC }\end{array}$ & - & НерВ & - & - & $\begin{array}{l}\text { MMR } \\
\text { PNEu }\end{array}$ & - & $\begin{array}{l}\text { DTaP } \\
\text { IPV } \\
\text { MMR }\end{array}$ \\
\hline Canada & НерВ & НерВ & $\begin{array}{l}\text { DTaP } \\
\text { IPV } \\
\text { Hib } \\
\text { PNEu } \\
\text { MENI }\end{array}$ & НерВ & $\begin{array}{l}\text { DTaP } \\
\text { IPV } \\
\text { Hib } \\
\text { PNEU } \\
\text { MEN1 }\end{array}$ & - & $\begin{array}{l}\text { DTaP } \\
\text { IPV } \\
\text { Hib } \\
\text { MENI }\end{array}$ & - & - & $\begin{array}{l}\text { MMR } \\
\text { VAR } \\
\text { PNEu }\end{array}$ & $\begin{array}{c}\text { DTaP } \\
\text { I PV } \\
\text { Hib } \\
\text { MMR }\end{array}$ & $\begin{array}{l}\text { DTaP } \\
\text { IPV } \\
\text { MMR }\end{array}$ \\
\hline America & НерВ & - & $\begin{array}{l}\text { HepB } \\
\text { DTap } \\
\text { Hib } \\
\text { IPV } \\
\text { PNEu } \\
\text { RV }\end{array}$ & - & $\begin{array}{l}\text { DTap } \\
\text { Hib } \\
\text { IPV } \\
\text { PNEu } \\
\text { RV }\end{array}$ & - & $\begin{array}{c}\text { HepB } \\
\text { DTaP } \\
\text { Hib } \\
\text { IPV } \\
\text { RV } \\
\text { PNEu }\end{array}$ & - & - & $\begin{array}{l}\text { Hib } \\
\text { MMR } \\
\text { PCV } \\
\text { VAR } \\
\text { DTaP }\end{array}$ & - & $\begin{array}{c}\text { IPV } \\
\text { DTaP } \\
\text { MMR } \\
\text { VAR }\end{array}$ \\
\hline
\end{tabular}


Table 3. Reported cases of disease.

\begin{tabular}{|c|c|c|c|c|c|c|c|c|c|c|}
\hline Disease & Country year & Diphtheria & $\begin{array}{c}\text { Japanese } \\
\text { encephalitis }\end{array}$ & Measles & Mumps & $\begin{array}{c}\text { Whooping } \\
\text { cough }\end{array}$ & Polio* & Rubella & $\begin{array}{c}\text { Neonatal } \\
\text { tetanus }\end{array}$ & $\begin{array}{c}\text { Tetanus } \\
\text { (total) }\end{array}$ \\
\hline \multirow{4}{*}{ Iran } & 2006 & 26 & - & 220 & - & 89 & 0 & - & 7 & 11 \\
\hline & 2007 & 32 & - & 133 & - & 267 & 0 & 20 & 3 & 11 \\
\hline & 2008 & 52 & - & 127 & - & 605 & 0 & 14 & 4 & 10 \\
\hline & 2006 & 1 & 7647 & 99,602 & 273,242 & 2595 & 0 & 37,137 & 2519 & - \\
\hline \multirow[t]{3}{*}{ China } & 2007 & 0 & 4330 & 320.109 & 252,701 & - & 0 & 74,746 & 2112 & 2112 \\
\hline & 2008 & 0 & 2975 & 144.131 & 310,826 & 2387 & 0 & 120,345 & 1786 & 1786 \\
\hline & 2006 & - & - & - & - & - & 0 & - & 10 & 10 \\
\hline \multirow[t]{2}{*}{$\begin{array}{l}\text { South } \\
\text { Africa }\end{array}$} & 2007 & - & - & 31 & - & - & 0 & 1072 & 3 & 3 \\
\hline & 2008 & - & - & 39 & - & - & 0 & - & 1 & 1 \\
\hline \multirow{3}{*}{ Australia } & 2006 & - & - & - & - & - & 0 & - & - & - \\
\hline & 2007 & 0 & - & 11 & 579 & 5379 & 0 & 36 & 0 & 3 \\
\hline & 2008 & 0 & 1 & 65 & 286 & 14,435 & 0 & 38 & 0 & 4 \\
\hline \multirow{3}{*}{ England } & 2006 & 3 & 0 & 764 & 5691 & 478 & 0 & 30 & 0 & 3 \\
\hline & 2007 & 3 & 0 & 1023 & 2569 & 1163 & 0 & 31 & 0 & 4 \\
\hline & 2008 & 5 & 0 & 1445 & 262 & 1028 & 0 & 30 & 0 & 5 \\
\hline \multirow{3}{*}{ Canada } & 2006 & 0 & 0 & 13 & 37 & 1945 & 0 & 7 & - & 2 \\
\hline & 2007 & 5 & - & 101 & 1108 & 1472 & 0 & 1 & 0 & 5 \\
\hline & 2008 & 1 & - & - & - & - & 0 & - & - & - \\
\hline \multirow{3}{*}{ America } & 2006 & 0 & - & 55 & 6339 & 15,632 & 0 & 11 & 0 & 41 \\
\hline & 2007 & 0 & - & 43 & 800 & 1045 & 0 & 12 & 0 & 28 \\
\hline & 2008 & 0 & - & - & - & - & 0 & - & - & - \\
\hline
\end{tabular}

*Polio refers to all polio cases (indigenous or imported), including polio cases caused by vaccine derived from polio viruses (VDPU); but does not include cases of vaccine-associated paralytic polio (VAPP) and cases of non-polio acute paralysis (AFP) Flaccid.

2006, and dropped to 90\% in 2007 and 2008.

\section{Discussion}

At present, routine vaccination against measles, polio, diphtheria, tetanus, whooping cough and tuberculosis is presented in all developing countries. New vaccines have also added to the basic program which was standard over the years, including hepatitis B vaccine, which has been recommended currently by the World Health Organization to all nations and is offered to infants for 147 of 192 WHO member states.

Immunization against Haemophilus influenza type B that is recommended in states according to available resources and the burden of disease is now available in vaccination program of 89 countries [11].

For example, the vaccine is not included in the EPI program of Thailand and most of the developing Asian countries, because the relatively low burden of disease [12], that in the results of the present study, Haemophilus influenza vaccine is not implemented in the same approach.

WHO recommended vaccines relevant to diseases in routine program for people living in areas with high risk of vaccine-preventable diseases has [13]. According to comparisons performed in the countries of our study, Japanese encephalitis and hepatitis A vaccines were prescribed to children only in China.

Varicella vaccine in Australia, America and Canada is part of the routine program, Meningitis Vaccine runs in China, Australia and the UK. Pneumococcal vaccine runs in South Africa, England, Canada and America and rotavirus vaccine is offered in the United States, Australia and South Africa. Availability to new additional vaccines and supportive technologies to further reduce the burden of infectious diseases will be effective until 2015, especially for countries that have been most affected by these diseases [14]. 
Table 4. Estimated vaccination coverage (\%).

\begin{tabular}{|c|c|c|c|c|c|c|c|}
\hline Vaccine & Country year & DTP3 & POl3 & BCG & НерВ3 & Hib3 & MCV \\
\hline \multirow{3}{*}{ Iran } & 2006 & 98 & 99 & 99 & 98 & - & - \\
\hline & 2007 & 99 & 98 & 99 & 97 & - & - \\
\hline & 2008 & 99 & 99 & 99 & 99 & - & - \\
\hline \multirow{3}{*}{ China } & 2006 & 93 & 94 & 92 & 91 & - & 86 \\
\hline & 2007 & 93 & 94 & 94 & 92 & - & 93 \\
\hline & 2008 & 97 & 99 & 97 & 95 & - & 94 \\
\hline \multirow{3}{*}{ South Africa } & 2006 & 81 & 65 & 81 & 67 & 67 & 62 \\
\hline & 2007 & 81 & 65 & 81 & 67 & 67 & 62 \\
\hline & 2008 & 81 & 65 & 81 & 67 & 67 & 62 \\
\hline \multirow{3}{*}{ Australia } & 2006 & 97 & 92 & \multirow{3}{*}{$\begin{array}{l}\text { Not available in } \\
\text { the program of } \\
\text { the country }\end{array}$} & 95 & 95 & 94 \\
\hline & 2007 & 97 & 92 & & 94 & 94 & 94 \\
\hline & 2008 & 97 & 92 & & 94 & 94 & 94 \\
\hline \multirow{3}{*}{ England } & 2006 & 92 & 92 & - & - & 92 & 85 \\
\hline & 2007 & 92 & 92 & - & - & 92 & 86 \\
\hline & 2008 & 92 & 92 & - & - & 92 & 86 \\
\hline \multirow{3}{*}{ Canada } & 2006 & 94 & 94 & - & 14 & 94 & 94 \\
\hline & 2007 & 94 & 90 & - & 14 & 94 & 94 \\
\hline & 2008 & 94 & 90 & - & 14 & 94 & 94 \\
\hline \multirow{3}{*}{ America } & 2006 & 96 & 93 & - & 93 & 93 & 92 \\
\hline & 2007 & 95 & 93 & - & 93 & 93 & 92 \\
\hline & 2008 & 96 & 23 & - & 93 & 93 & 92 \\
\hline
\end{tabular}

Mark __ means that the vaccine coverage is not recorded.

In studied developed countries (America, Australia and Canada) probably due to the uncommon cases of tuberculosis, BCG vaccine is not included in their routine program.

Vaccination action plan recommended by WHO for all children is the administration of one dose of BCG, three doses of DTP vaccine, three doses of OPV or IPV, three doses of hepatitis B, one dose of measles or with rubella and mumps. Three doses of Haemophilus influenza vaccine are also recommended [13].

Although the recommended WHO program for the administration of triple vaccine is at three different stages (usually at the ages of 6,10 and 14 weeks), this case is different from one country to another. Developing countries such as Africa, South Asia and East Asia follow the program. A four-step program that is also coupled with a reminder in the second or third year of life runs in European countries, while the five-step program, along with 2 reminders runs in Latin America [8]. In the countries of our study, Australia and the United Kingdom follow the 4-step program and Canada, America, South Africa, China and Iran follow the 5-step program of DTP vaccine administration.

Some countries use the killed injectable polio vaccine (IPV) and others use oral polio vaccines (OPV) containing live virus. Among the countries of our study, Canada, America, Australia and the United Kingdom use IPV and Iran, South Africa and China use OPV.

Vaccine providers should report all observed cases of vaccine-preventable diseases. Disease surveillance systems are essential tools for studying the effectiveness of health systems for the following reasons: 1) An early awareness of disease outbreak; 2) providing essential information for the management of immunization programs, accordingly strengthening the surveillance systems is vital as part of the expanded immunization program [8], but despite the ongoing efforts to develop disease surveillance systems, many countries were encountered challenges in detection, diagnosis and proper reporting of infectious diseases, because of the remoteness of communities, lack of transport and communication infrastructure, shortage of skilled workers in healthcare and laboratory facility in order to ensure a correct diagnosis and in many developing regions due to lack of access to 
laboratory testing, disease reporting has been merely made on the basis of the clinical signs and symptoms diagnosis. Therefore, the number of reported cases cannot be used to indicate the amount of effort or progress of a particular country in disease control or to determine the burden of disease in countries [15].

As Table 3 shows reported cases of disease it should be considered that such cases are not valuable information in terms of quality and reliability, comparability and true representation, due to the high diversity.

On the other hand, the choice of diseases available was solely based on the data available. The numbers are not an index for the relative risk of diseases and the quality of disease reports in studied countries. These numbers need to be interpreted according to the epidemiological patterns of diseases and how to collect data related to the disease in each country.

Table 4 shows the percentage of estimated vaccination coverage. Assessing levels of vaccination coverage in the community is an important strategy to improve vaccination coverage rates [16].

Data on immunization coverage are used for various purposes: monitoring vaccination services at local, national and international levels, guidelines for the eradication, elimination and control of vaccine-preventable diseases, identifying areas of weakness in the system that may need additional resources and focused attention and making decisions about entering new vaccine into the program [17] [13].

One of the third Millennium Goals by 2010 is to ensure full immunization of children under the age of one year with national coverage of $90 \%$ and minimum regional coverage of $80 \%$ [18]. That, all studied countries have achieved this goal, except South Africa.

The coverage levels of the third dose of DTP vaccine $\left(\mathrm{DTP}_{3}\right)$, which is injected at the age of 12 - 23 months, are used as the best and most common indicator of health system performance and how to monitor immunization coverage levels [8] [9] [19].

In Britain, America and Canada, the coverage rate of BCG vaccination has not been reported, however, in America and Canada the BCG vaccine is not included in their routine program, but it is available in the routine immunization program of England, however, immunization coverage rates have been reported, that may be because in most countries BCG vaccine is administrated immediately or shortly after birth in hospital by hospital personnel, thus the coverage rate is not reported, regularly [9].

\section{Conclusion}

As can be seen in Table 4, the coverage rate of the vaccine $\left(\mathrm{DTP}_{3}\right)$ and other vaccines in Iran was the best compared to other countries. This represents the widespread activity of health care systems of the country in the field of vaccination and tireless efforts of healthcare workers and health centers.

\section{References}

[1] Mehr, A. (2008) Comprehensive Textbook of Clinical Immunizationin Preventive Medicine. Khosravi Pub., Tehran, 23-30.

[2] UNICEF. Immunization-Expanding Immunization Coverage. Unit for Children. http://www.unicef.org/immunization/index_coverage.html

[3] El-Tayeb Ahmed, E.S. (2006) Highlights on the Expanded Programon Immunization (EPI) in Sudan. Sudanese Journal of Public Health, 1, 152-158.

[4] Borras, E., Dominguez, A., Batalla, J., Torner, N., Cardenosa, N., Nebot, M., Plasencia, A. and Salleras, L. (2007) Vaccination Coverage in Indigenous and Immigrant Children under 3 Years of Age in Catalonia (Spain). Vaccine, 25, 3240-3243.

[5] Ehreth, J. (2003) The Global Value of Vaccination. Vaccine, 21, 596-600. http://dx.doi.org/10.1016/S0264-410X(02)00623-0

[6] Barker, L.E. and Luman, E.T. (2001) Changes in Vaccination Coverage Estimates among Children Aged 19-35 Months in the United States, 1996-1999. American Journal of Preventive Medicine, 20, 45.

[7] (2006) Immunization Snap Shots. News, Documents and Tools on Routine Immunization and Sustainable Financing February 2006/Issue 2. Coverage Confusion! Trying to Make Sense of It.

[8] Bos, E. and Batson, A. (2000) Using Immunization Coverage Rates for Monitoring Health Sector Performance. Measurement and Interpretation Issues. HNP Discussion Paper, August 2000.

[9] (2008) World Health Organization. Department of Immunization, Vaccine and Biologicals. Vaccine-Preventable Diseases: Monitoring System, 2008 Global Summary, Geneva 27-Switzerland. 
[10] Zahraei, S.M., Marandi, A., Sadrizadeh, B., Gouya, M.M., Rezaei, P., Vazirian, P., et al. (2010) Role of National Immunization Technical Advisory Group on Improvement of Immunization Programmes in the Islamic Republic of Iran. Vaccine, 28, A35-A38.

[11] (2005) World Health Organization. Immunization against Diseases of Public Health Importance, the Benefits of Immunization. Fact Sheet No 288. March 2005.

[12] Chokephaibulkit, K., Phongsamart, W., Vanprapar, N., Chotpitayasunondh, T. and Chearskul, S. (2004) Catch-Up Vaccination against Haemophilus Influenzae Type b in Human Immunodeficiency Virus-Infected Thai Children Older than 2 Years Old. Vaccine, 22, 2018-2022. http://dx.doi.org/10.1016/j.vaccine.2003.10.033

[13] Burton, A., Monach, R., Lautenbach, B., Gacic-Dobo, M., Neill, M., Karimov, R., Wolfson, L., Jones, G. and Birmingham, M. (2009) WHO and UNICEF Estimates of National Infant Immunization Coverage: Methods and Processes. Bulletin of the World Health Organization, 87, 535-541. http://dx.doi.org/10.2471/BLT.08.053819

[14] WHO (2005) Immunization Service Delivery and Accelerated Disease Control. New Vaccines and Technologies.

[15] WHO (2009) World Health Statistics. Selected Infectious Diseases. 59-69.

[16] Dayan, G.H., Orellana, L.C., Forlenza, R., Eliss, A., Chaui, J., Kaplan, S. and Strebel, P. (2004) Vaccination Coverage among Children Aged 13 to 59 Months in Buenos Aires, Argentina. Pan American Journal of Public Health, 16, 158167.

[17] (2013) World Health Organization, WHO-UNICEF Estimates of DTP3 Coverage. December 26, 2013. http://apps.who.int/immunization monitoring/globalsummary/timeseries/tswucoveragedtp3

[18] WHO-Immunization, Vaccines and Biologicals. http://www.who.int/immunization/givs/goals/en/index.htmL.8thJan 2009

[19] (2006) Challenges in Global Immunization and the Global Immunization Vision and Strategy 2006-2015. Weekly Epidemiological Record, 81, 189-196.

\section{Abbreviations}

EPI: Expanded Program Immunization

VPDs: vaccine-preventable diseases

RR: Relative Risk 
Scientific Research Publishing (SCIRP) is one of the largest Open Access journal publishers. It is currently publishing more than 200 open access, online, peer-reviewed journals covering a wide range of academic disciplines. SCIRP serves the worldwide academic communities and contributes to the progress and application of science with its publication.

Other selected journals from SCIRP are listed as below. Submit your manuscript to us via either submit@scirp.org or Online Submission Portal.
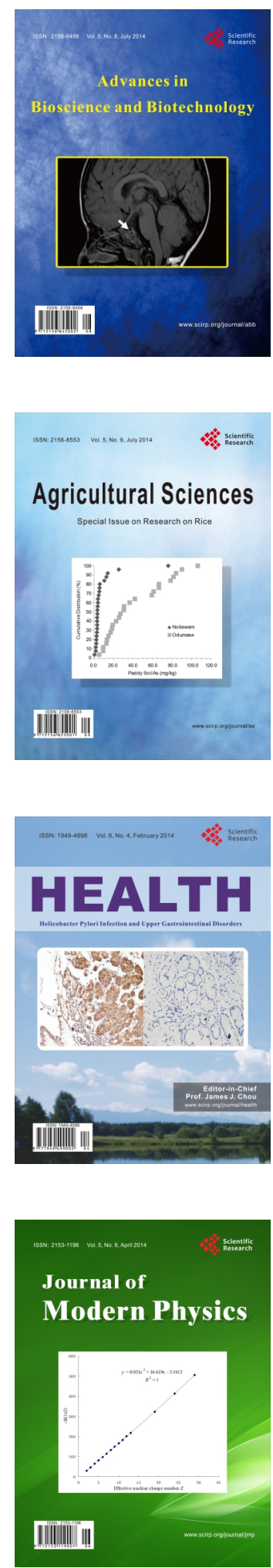
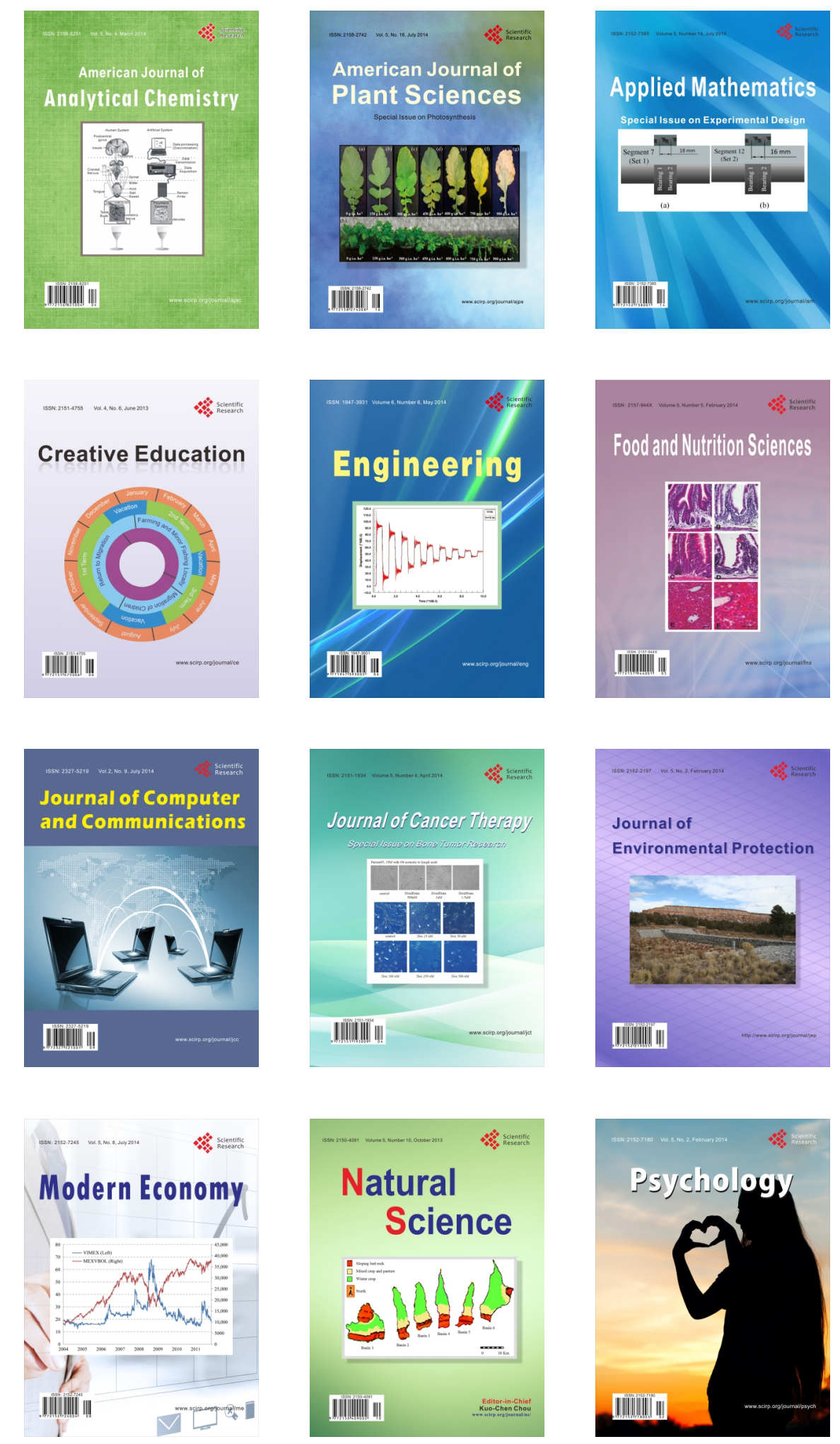